\title{
Knife handle making - the subsidiary trades in the Sheffield cutlery industry
}

La fabrication de manches de couteaux à Sheffield. Les sous-traitants dans l'industrie de la coutellerie

\section{Joan Unwin}

\section{(2penEdition}

\section{Journals}

Electronic version

URL: http://journals.openedition.org/artefact/1237

DOI: 10.4000/artefact.1237

ISSN: 2606-9245

\section{Publisher:}

Association Artefact. Techniques histoire et sciences humaines, Presses universitaires du Midi

\section{Printed version}

Date of publication: 30 May 2018

Number of pages: $107-120$

ISBN: 978-2-7535-7494-6

ISSN: $2273-0753$

Electronic reference

Joan Unwin, "Knife handle making - the subsidiary trades in the Sheffield cutlery industry ", Artefact [Online], 7 | 2017, Online since 30 January 2019, connection on 04 March 2020. URL : http:// journals.openedition.org/artefact/1237 ; DOI : https://doi.org/10.4000/artefact.1237 


\title{
Knife handle making - the subsidiary trades in the Sheffield cutlery industry
}

Joan $U_{N W I N}^{*}$

\begin{abstract}
This paper will explore the documentary evidence and surviving examples to understand the work practices, rates of pay and the supply of material for subsidiary trades associated with the Sheffield knife-making industry. Metal working has been well researched but little has been done to appreciate the details of the trades which used bone, ivory, horn, etc. to make the knife handles, where the use of these materials was governed by availability, price and fashion.
\end{abstract}

Keywords : Bone, horn, ivory, knives, Sheffield, work practices

\section{Résumé. La fabrication de manches de couteauxà Sheffield. Les sous-traitants dans l'industrie de la coutellerie.}

À partir de l'étude de documents d'archives et de couteaux de Sheffield encore conservés de nos jours, cet article a pour objectif de comprendre les méthodes de travail, les taux de rémunération et l'approvisionnement en matière première des métiers subsidiaires en lien avec cette industrie. Si le travail du métal a été bien étudié, peu de recherches permettent, en revanche, d'apprécier en détail les métiers qui utilisent l'os, l'ivoire, la corne, etc. pour fabriquer les manches de couteaux, l'utilisation de ces matériaux dépendant de leur disponibilité, de leur prix et de la mode alors en vigueur.

Mots clés : corne, couteaux, ivoire, méthodes de travail, os, Sheffield.

\footnotetext{
*. $\mathrm{D}^{\mathrm{r}}$ Joan Unwin is the Archivist to the Company of Cutlers in Hallamshire, UK. For twelve years she was also a researcher at Sheffield University working on the Hawley Collection of cutlery and edgetools. Her research has been into the Sheffield cutlery industry and the Cutlers' Company records, particularly the manufacturing processes and controls by the Cutlers' Company during the $17^{\text {th }}$ and $18 \mathrm{t}^{\mathrm{h}}$ centuries. Contact : [Joan@cutlers-hallamshire.org.uk].
} 


\section{Background}

For centuries, the Sheffield area in the north of England has produced ferrous metal goods, notably knives and edge tools. By the early XVII ${ }^{\text {th }}$ century, the majority of its inhabitants were directly or indirectly involved in the trade, which was carried out in small workshops often adjacent to houses. The cutlery trade was overseen by a craft guild - the Company of Cutlers in Hallamshire, established by a Parliamentary Act of Incorporation in 1624. It registered apprenticeships and dictated that cutlery products had a cutting edge made of steel, and was empowered to pass by-laws and exact fines. Their records of apprentices indicate the growth of the industry and local work practices, which involved hand-forging blades from iron and steel bars, grinding a cutting edge and then assembling knives, or scissors, or shears, etc. These craft and the later industrial processes have been well-researched and understood. In his seminal work, GIH Lloyd in 1913, was able to observe processes and practices common in the $19^{\text {th } 1}$. A later relevant publication is by Sidney Pollard, giving a more quantitative evaluation of midXIX $^{\text {th }}$ century Sheffield ${ }^{2}$.

However, little has been written about the subsidiary trades which supplied the cutlery industry. This paper will consider the several occupations making a variety of handles from animal hard parts - ivory, horn, antler, pearl, bone and tortoiseshell. Some of the manufacturing processes can be deduced from surviving knives in museums, but little is known about the workers in the midXIX ${ }^{\text {th }}$ century, such as how many women and children were employed. Using the unique source of compensation claims made after a flood in Sheffield in 1864, together with census material and a government commission, it is possible to reconstruct the socio-economic role of mid-XIX ${ }^{\text {th }}$ century handle making trades. Online sources have opened further research possibilities.

The basic processes of knife making have changed little over the centuries, changes being in improved iron and steel and in machines. Because knives are small objects, men could easily set up a workshop, requiring only a workbench and a small smithy fire. This space would enable him to forge blades from heated rods of metal and attach various types of handles. Grinding the blades was mainly carried in the waterpowered workshops along the river valleys just outside Sheffield. After the 1780s, power to tenement factories was supplied by steam engines, then by gas engines, power being transmitted to the workshops by line shafts and drive belts. Cutlers could rent these work space and power, often having workshops in crowded tenement buildings, which also housed people working with the animal parts that they would use for handles. 


\section{Knife Handles}

Metal blades come in many shapes and sizes, but they all require a handle for safe usage. To some extent the handle is determined by function, but it can also be for display, showing the craftsman's skill and the owner's wealth. Manufacturers were well aware of the market for quality handles, and followed the latest fashion. It is interesting that knives in personal and public collections are usually described in terms of their handle material and most have survived to become collectors' pieces because of their attractiveness. The simplest handles are made from readily available materials - wood, bone, cattle horn or antler. Non-organic handles were made from ceramics, glass, attractive minerals such as agate, or metals, such as silver and gold. And all handles could be enhanced by skilled craftsmen, with inlays, staining, carving or mixtures of decorative methods, more so with the expensive materials.

The physical characteristics of the animal hard parts, osseous and keratinous material, determines the types of handle which can be made ${ }^{3}$. Osseous material is derived from long bones and antlers, which have a dense outer part around a spongy core. Handle material from antlers and horns of deer (Cervidae) is termed 'stag' or 'stag horn' in the Sheffield cutlery trade. Teeth, usually termed 'ivory', come notably from elephant, but also marine mammals, wild pig and hippopotamus. There is also 'vegetable ivory' derived from the tagua nut of various species of American palm. Its hard white flesh mimics the more expensive elephant ivory, making it suitable for carved and stained buttons and jewellery. Keratinous material is protein-based and is a thermoplastic substance which can be used in thin sheets, examples being horn, hoof, tortoiseshell and 'whale bone' or baleen. Another desirable material is pearl, derived from the shells of large marine molluscs.

Pearl and all types of ivory are sufficiently dense to be used for solid, round or rectangular knife handles, down which is bored a hollow to take a narrow round tang (Fig. 1). Antler can also be used for solid handles, either as the antler tips, used typically on carving knives, or as cut sections when the exposed core of the antler is covered with a decorative metal end cap. Only thin rectangular sections can usefully be cut from long bone, ribs or scapulae and these are called 'scales'. Leftover pieces of ivory, pearl and antler can also be cut into these thin scales. These partly-

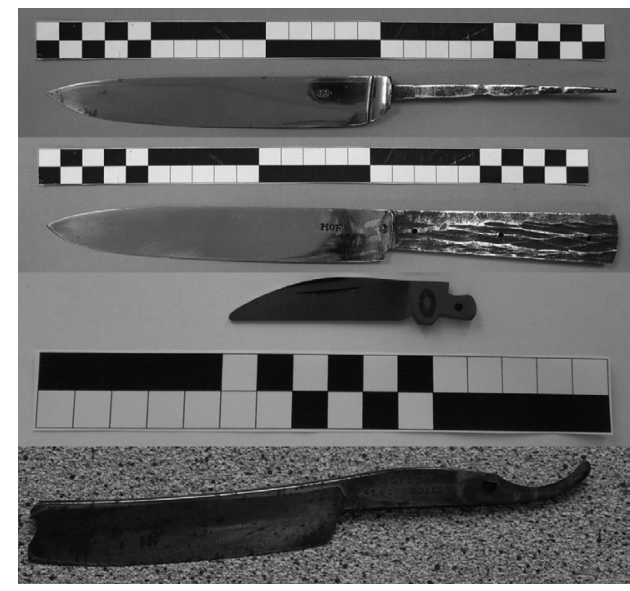

Fig. 1. - Examples of blades, top, table blade with a round tang and below with a flat tang; centre, a folding pocket knife blade; bottom, an open razor blade. 
prepared pieces, scales and rectangular pieces, were sold to cutlers as 'blanks'.

Knives with a variety of handles survive in museums and private collections where it is possible to see the vast range of styles and decoration but a recent source of part-made handles and waste material comes from the many archaeological excavations around
Sheffield. Over the last twenty years redevelopment of the city centre has resulted in the demolition of a number of old factories. Large amounts of bone off-cuts and waste have been found, confirming work processes, but very little of the more costly materials has been found, as they would be scavenged when a building became empty.

\section{Handle manufacture - data sources}

There are few contemporary descriptions of the $\mathrm{XIX}^{\text {th }}$ century trades working with osseous and keratinous parts of animals in the cutlery industry, and hardly any first-hand accounts ${ }^{4}$, though it is possible to see some of the processes carried out by today's craftsmen wishing to continue some of the traditions. One description however, comes in an extensive guide to turning on a lathe and other manipulations of animal and vegetable derived materials. This was not a factory instruction manual, but gave detailed information for the mid-Victorian gentleman hobbyist ${ }^{5}$.

Sheffield has one valuable and unique resource - the compensation claims made by victims of a disastrous flood. Late in the night of 11 March, 1864, high above the town of Sheffield, a newly built dam wall across the River Loxley burst and flood water surged down the narrow river valley, destroying houses and water-powered workshops. As the water reached the outer suburbs of Sheffield, the Loxley joined the River Don and water spread out over the flatter land, carrying with it trees, machinery, animals and bodies. The river flowed through the town centre and on towards Doncaster to the north-east. 240 people died and there was extensive damage to factories, workshops and houses 6 . The 11 volumes of compensation claims, kept at Sheffield Archives, have been transcribed by Sheffield Hallam University ${ }^{7}$, now online as a searchable database and provides a very detailed insight into people's lives. Relevant to this paper, the claims contain details of the people who had any animal-based items in their possession - merchants of raw materials and part-finished goods; shopkeepers selling goods, part or wholly made of animal parts; craftsmen using the products to make knives and finally, people who used bone waste and dust as fertiliser. The valuations of goods and services are fascinating, as were the many claims for loss of wages.

There were just over 6500 claims for compensation in total. These compensation claims were searched on line using the keywords of ivory, bone, horn, stag, tortoiseshell and pearl and each claim number is used as reference 
here. The claims ranged from loss of earnings to loss and damage to stock. From these is possible to appreciate the size of trade in animal parts, the interdependence within the cutlery industry and descriptions which show the range and variety of uses.

The growing interest in family history and ancestry has fuelled increasing sources of online data having searchable transcriptions. For this paper, the published data for the 1841-1891 tenyearly censuses of Britain were searched for occupations in the Sheffield area. A typical website is 'Free $\mathrm{Cen}^{\prime 8}$, which gives the names of people, their ages, sex, occupations, where born and where resident. There is nowhere near a blanket coverage of these transcriptions for the $\mathrm{UK}$, which is dependent on volunteers, but there is sufficient to be useful and coverage will continue to increase. Searches were made using keywords relating to occupations involving the use of animal material with an insight into the high degree of specialisation by workers.
Censuses in the UK began in 1801, but individuals were only listed after 1841. The whole of the UK was divided into enumeration districts and the census takers would go from house to house recording residents and visitors in notebooks, which were then entered into standard sheets. These sheets have been microfilmed and are available locally at libraries and archives and the transcription of all this data into spreadsheets has made it accessible for massive online searches, previously virtually impossible. Online coverage of the UK is patchy and it is acknowledged that errors will have crept in at all stages of the census gathering processes. Sheffield was within the West Riding of Yorkshire, now known as South Yorkshire. There are currently 400000 transcribed records for the 1861 West Riding of Yorkshire census and around four hundred people involved in the use of animal hard parts were found in the online searches for Sheffield (Table 1). About $10 \%$ of the Sheffield area data is available online for the years 1861, 1871 and 1891 and though this is not a large coverage, it is sufficient

\begin{tabular}{|l|l|l|l|l|l|l|}
\hline Material & $\begin{array}{l}\text { Total } \\
\text { number } \\
\text { of worker }\end{array}$ & $\begin{array}{l}\text { Working } \\
\text { in cutlery } \\
\text { related } \\
\text { crafts }\end{array}$ & $\begin{array}{l}\text { Working in non- } \\
\text { cutlery related } \\
\text { crafts }\end{array}$ & $\begin{array}{l}\text { Number of } \\
\text { males }\end{array}$ & $\begin{array}{l}\text { Number of } \\
\text { females }\end{array}$ & $\begin{array}{l}\text { Age } \\
\text { ranges } \\
\text { (years) }\end{array}$ \\
\hline Bone & 114 & $96(84 \%)$ & 18 & 104 & 10 & 11 to 84 \\
\hline Ivory & 76 & $72(95 \%)$ & 4 & 69 & 7 & 10 to 72 \\
\hline Pearl & 91 & $66(73 \%)$ & 25 & 84 & 7 & 10 to 69 \\
\hline Horn & 109 & $88(81 \%)$ & 21 & 98 & 11 & 6 to 72 \\
\hline Stag & 31 & $30(97 \%)$ & 1 & 30 & 1 & 12 to 63 \\
\hline
\end{tabular}

Table 1. - Quantitative data from the 1861 census for the Sheffield area in the West Riding of Yorkshire. The table shows few women and girls in the work force, and the age ranges show very young children were employed, usually working with their parents or relatives. The most common job was cutting in all materials and is counted as cutlery related. Non-cutlery trades included button and comb making. 
to show some of the contemporary diversity in the cutlery sub-trades.

A further source for this paper is the government report into children's employment in $1863^{\circ}$. Investigating

\section{Bone}

Bone was the most readily available and cheapest of animal hard parts. After bone was cleaned, the shafts of long bones were generally sawn into handle lengths of about $100 \mathrm{~mm}$, and then each piece had four longitudinal cuts to remove the dense, outer bone from the core. These rectangular pieces with a semicircular cross section were called 'scales'. Waste bone consisted of small 'boxlike' sections where the semi-circular pieces had been sawn off and the ends of long bones (Fig. 2). Flat scales could also be sawn from ribs and scapulae. Small bones, such as metapodials, have a perfect, ready-made shape for knife handles. Examples of such handles have been found at the Sylvester Wheel in Sheffield, where an excavation by the Archaeological Research Consultancy University of Sheffield recovered a number of metapodials, cut to handle length and decorated with incised straight lines ${ }^{10}$. None has been seen on knives, however.

From the 1861 census search, workers in bone was the largest group and almost all were described as bone cutters and bone scale cutters. Most non-cutlery workers were involved in making bone buttons. Merchants and larger manufacturers bought in the conditions in manufacturing processes across the country, the Commissioners came to Sheffield and inquired into the metal industries, including handle making for the cutlery trade.

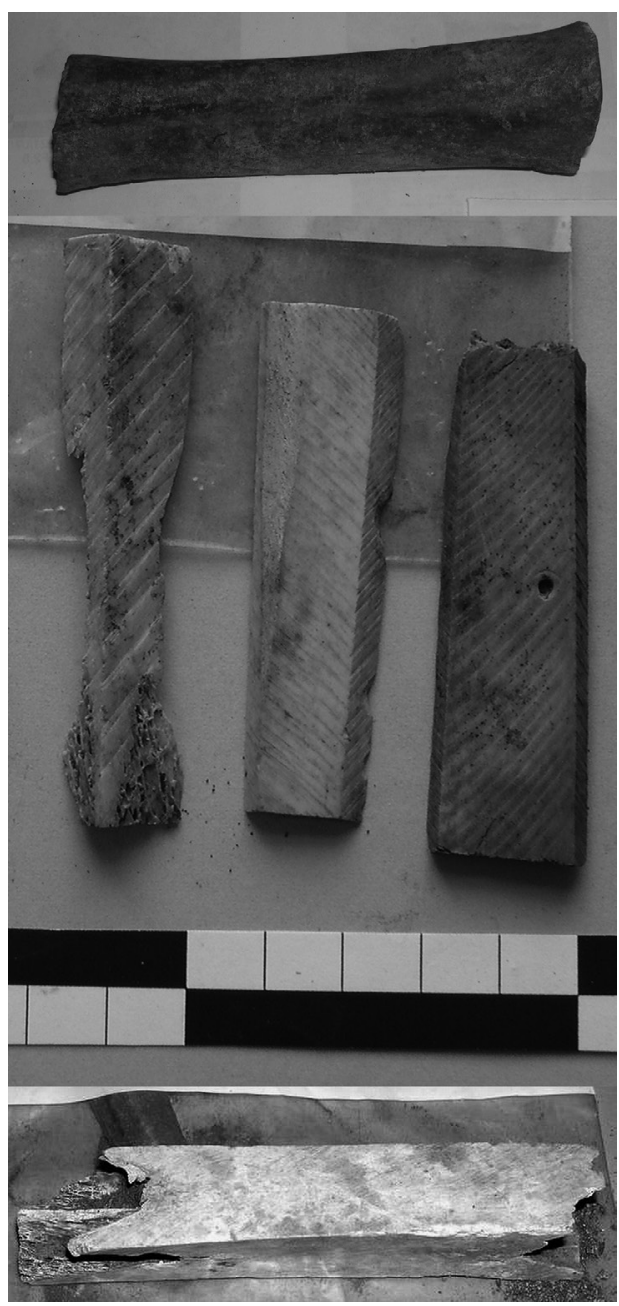

Fig. 2. - Excavated bone; top, bone shaft sawn to length; centre, scales showing saw marks; bottom, waste bone. 
raw material to render and prepare the handle pieces, known as 'blanks', then individual cutlers could buy these as and when required. The ages for the bone workers ranged from 13 to 66 years old, with indications that younger people worked in the same trade as their parent. Other bone workers in this census were in the bone mills, boiling and grinding bone, as labourers and dealers. There were also 'rag and bone' men, who toured the streets with a cart, collecting usable clothing and household goods, sometimes repaying with a piece of crockery. They have not been included in the Table 1. of $£ 1$ in 1864 having $£ 88$ in purchasing power in $2016^{11}$. It is emphasised that the claims were scrutinised before they were settled and the vast majority received about what they claimed.

The sheer size of the claims is astonishing. Michael Hunter, a large cutlery manufacturer and H. \& E. Wilson, a bone and scale cutter, claimed for enormous amounts of stock (Table 3 ). That Wilson lost bone 'sawings' confirms the use of saws and also John Grayson, a bone cutter, claimed for eight circular saws.

\begin{tabular}{|l|c|l|}
\hline Material & $\begin{array}{l}\text { Number of indi- } \\
\text { vidual claims }\end{array}$ & Types of items listed in the claims \\
\hline Bone & 45 & $\begin{array}{l}\text { bones, bone shanks, dust, handles, penknives, sawings, } \\
\text { scales }\end{array}$ \\
\hline Ivory & 43 & $\begin{array}{l}\text { billiard balls, cigar cases, ivory, knives and forks, locket, } \\
\text { penknives, vegetable ivory, visiting cards }\end{array}$ \\
\hline Pearl & 18 & pearl ash, penknives \\
\hline Horn & 36 & dust, horn cuts, pressed scales, scales, tobacco pipes \\
\hline Stag & 23 & dust, knives, scales, stag, tines, \\
\hline
\end{tabular}

Table 2. - The number of claims relating to each of the types of material. Almost everyone working with these materials had quantities of dust, which had value. The numbers claiming for stag and horn is slightly confusing, as it is often unclear which material is being described, as the claims mention stag horn, horn or stag.

A more detailed insight into the bone trades comes from the compensation claims. Tables 2 has the terms used to describe goods and property, both personal and trade goods are included and Table 3 gives specific examples from the claims. Claim numbers are given as reference and the monetary values are in the appendix, based on the equivalent
One man, Nicholas Holman, was associated to the bone cutting processes. He was a 'tillage manufacturer' who profitably made use of bone waste. Bone was being used as fertiliser and other references to bone dust were often listed in people's gardening claims. Although bone was primarily used in the cutlery industry, it was a commodity which sup- 


\begin{tabular}{|c|c|c|c|c|}
\hline $\begin{array}{l}\text { Claim } \\
\text { reference } \\
\text { number }\end{array}$ & Claimant & Occupation & Details & Valuation \\
\hline 849 & George Digman & $\begin{array}{l}\text { merchant and } \\
\text { manufacturer }\end{array}$ & 684 ivory handle & $£ 5$ \\
\hline 1008 & John Coe & $\begin{array}{l}\text { cutlery } \\
\text { manufacturer }\end{array}$ & 2,880 bone handles & $£ 12$ \\
\hline 3320 & E \& H Wilson & $\begin{array}{l}\text { handle and scale } \\
\text { cutters }\end{array}$ & $\begin{array}{l}21 \text { tons bone shanks; } \\
4 \text { tons bone sawings }\end{array}$ & $\begin{array}{l}\text { No specified } \\
\text { value }\end{array}$ \\
\hline 3629 & James Thorpe & horn cutter & 5,200 horn cuts & $\begin{array}{l}\text { No specified } \\
\text { value }\end{array}$ \\
\hline 4574 & $\begin{array}{l}\text { Robert } \\
\text { Armitage }\end{array}$ & cutler & $\begin{array}{l}432 \text { pressed scales; } \\
432 \text { buffalo horn scales; } \\
264 \text { stag scales; } 72 \text { buf- } \\
\text { falo grey horn }\end{array}$ & $£ 7$ 18s. \\
\hline 4815 & Michael Hunter & $\begin{array}{l}\text { cutlery } \\
\text { manufacturer }\end{array}$ & $\begin{array}{l}20-30,000 \text { bones } \\
\text { and bone lengths; } \\
121,00 \text { bone various } \\
\text { handles; bone, stag and } \\
\text { horn dust }\end{array}$ & $£ 116$ \\
\hline 5110 & $\begin{array}{l}\text { Nicholas } \\
\text { Holman }\end{array}$ & $\begin{array}{l}\text { tillage } \\
\text { manufacturer }\end{array}$ & $\begin{array}{l}15 \text { tons bone dust; } 115 \\
\text { tons bone ash }\end{array}$ & $£ 197$ \\
\hline 5839 & $\begin{array}{l}\text { Stephen } \\
\text { Critchlow }\end{array}$ & $\begin{array}{l}\text { bone cutter and } \\
\text { ironmonger }\end{array}$ & $\begin{array}{l}\text { 198,921 various bone } \\
\text { handles }\end{array}$ & $£ 124$ \\
\hline 5856 & Anthony Guest & $\begin{array}{l}\text { bone button } \\
\text { manufacturer }\end{array}$ & $\begin{array}{l}6 \text { tons bone dust; } 2 \text { tons } \\
\text { vegetable ivory }\end{array}$ & $£ 78$ \\
\hline
\end{tabular}

Table 3. - Examples of claims relating to handle making. Amount of goods in the claims are given in gross and dozens, but have been converted to numbers here.

ported several other trades, and one can deduce that it was very unhealthy work, which generated so much dust.

The most comprehensive bone claim was by Stephen Critchlow, a bone and scale cutter, who was listed in the 1861 census as a bone cutter and ironmonger with his 14 year-old son. His claim was for 1301 gross octagon-shaped bone handles of varying lengths and prices. The standard quantities were always counted in a dozen (12) or a gross $(12 \times 12=144)$ and fractions of these amounts. Again, these amounts are huge, 1301 gross is 187344 octagon handles. He also had 11577 scales, i.e. thin slices of bone, described as spear scales, giving a grand total of around 200000 worked bone pieces. These quantities, just from one merchant, demonstrate the size and diversity of the knife handle trade. Critchlow's handles came in ten lengths, 
$23 / 4-41 / 2$ inches (70 mm - $114 \mathrm{~mm}$ ). Critchlow estimated the value of all these handles and scales at $£ 124$, but declared that he had managed to sell them at auction for $£ 53$, so claimed for a deficit of $£ 70$. Selling off flood-damaged stock is obviously not something new. Claims give prices per gross of handles and scales, typically at 2 shillings per gross, an incredibly small amount given the labour involved in producing them but there were smaller claims with varying prices indicating superior quality. Selling so many variations must have been a nightmare, as cutlers would not want a gross of each different size and so would only buy in dozens or part dozens. This evidence of the range of handle sizes and willingness to supply large and very small amounts to cutlers were factors in the continuation of small-scale production. It was not feasible to install costly machinery which did not have the versatility for such size variation.

Working with bone was a potentially harmful occupation. Sheffield was known for the poor conditions in some of the cutlery processes, especially in grinding blades on natural sandstones. The stone and steel dust in the workshops' atmosphere contributed to lung diseases and early deaths, but little

\section{Ivory}

Supplies of exotic pearl, ivory, tortoiseshell and horn were imported into England from a variety of sources, following trade routes out of Africa, India and the Far East. They were much more expensive than bone. By the middle of has been said about sawing and turning bone and ivory etc. It was well recognised that ventilation was important, but many people rented small workshops in larger factories and could not or would not install fans. Interviewing young children, the Commissioners found that they were working with steam driven circular saws to cut the bone into pieces. It is hard to imagine holding wet bone to be cut into $100 \mathrm{~mm}$ lengths, without accidents occurring. Cutting wet bone was preferable to dry bone, as it produced less dust, so people were aware of the problems with the dust in the atmosphere and that fans would improve the situation. The report into child employment talks of piles of dust swept into corners and children telling of breathing problems ${ }^{12}$. A 1933 report in the U.S. detailed another problem affecting workers in a bone button factory. A number were contracting erysipelas, which is a streptococcal infection of the skin transmitted from contaminated bone, typically in abattoirs and in workshops. It causes painful inflammation of the skin on the hands and arms, which lasts for two or three weeks ${ }^{13}$. No doubt this affected the workers in the bone workshops in $X X^{\text {th }}$ century Sheffield.

the $\mathrm{XIX}^{\text {th }}$ century, cutlery manufacturers in Sheffield had huge stockpiles of such materials and boasted of them in their catalogues and firms' histories. The most spectacular is in the booklet "Under Five Sovereigns" published by Joseph Rodgers 
and Sons in the early 1900s. Photographs show the stores of ivory and antlers and the text describes the ivory store as having 15 tons, valued at $£ 22,000$; the largest piece being $160 \mathrm{lbs}$, down to baby teeth of 1-2 $\mathrm{lbs}^{14}$. Some concern about the size of the ivory trade was noted in The Times newspaper in 1883, reporting that a large proportion of ivory at auction were very small teeth, a sign that many elephants were being killed at a young age. The article estimated that 5286 tons of ivory came into Britain between 1873 and 1881, totalling 296016 pairs of tusks, indicating how many elephants were killed for the British trade ${ }^{15}$. Ivory used for knives and razors could be plain and simple (Fig. 3) but it was more pleasing than bone. Of course, ivory was used for much more than knife handles.

The 1861 Census for the Sheffield area has 76 entries for ivory workers, the largest group being the cutters, and all but three being male, with ages ranging from ten years old to 60 years. The mother of the ten-year old boy, was also an ivory cutter, as was her other son, aged 12. From the census details, the woman was a 36 year old widow, who presumably

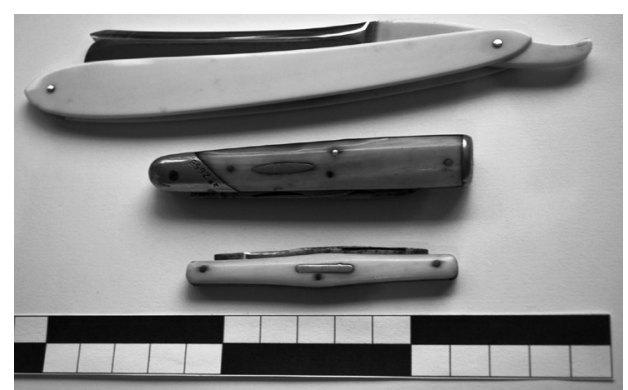

Fig. 3. - Ivory scales; top, plain open razor scales; centre; pocket knife with ivory scales and an inlaid shield; bottom; penknife with ivory scales and inlaid shield took her sons to work with her, in order to increase the family's income. To get an idea of income, an ivory cutter (6507) working at the Globe Works, claimed for 10 days loss of income at 7 shillings per day. Compensation claims included loss of clothing as well as goods, giving the value of these wages. A spring knife cutler (43) submitted a claim for two pairs of shoes at 15 shillings. It would therefore take a day's wage for an ivory cutter to buy a pair of shoes, costing 7 shillings.

Other job descriptions included ivory turners, all male, some of whom used lathes and machinery. Lathes and drills might be powered from a central steam engine, via line shafts and drive belts, or may be driven by a foot treadle. One unusual term in the census was a 'fluter'- men who produced beautiful and intricate decoration on handles. The term ivory carver was also used and a sizeable group of fluters also worked with pearl and the claims show roughly the same rate of pay in the ivory and pearl trade. The skill of the cutters, turners and carvers was crucial in working such an expensive material like ivory, as leftover pieces went into the button trade. Given the importance of maximising this expensive raw material, it is surprising that a ten-year-old boy was able to do the cutting.

Anthony Guest, a button manufacturer was awarded almost $£ 100$ compensation for his loss of stock, including over ten tons of bone dust and interestingly, two tons of vegetable ivory, valued at $£ 15$ per ton. He ran his business from the Soho Grinding Wheel, a large tenement factory, where he would rent space and power. He claimed almost $£ 7$ to pay 
20 employees' wages, which included six women employed as ivory button borers - making the holes in the buttons. His women were paid 8 shillings and two pences each for seven days' lost work. In comparison, a male ivory turner at the same works, claimed 28 shillings for seven days' work. These workers had made individual claims but were withdrawn, as happened elsewhere, when the employer had also claimed for this money.

Various claims for personal and shop goods give a fascinating list of ivory

\section{Pearl}

Ninety-one people working with pearl were listed in the 1861 census transcriptions for the Sheffield area. Twenty-eight people were listed as pearl cutters and a similar number as pearl button makers, including four women. The next largest group were the fluters. The women in the button trade were aged between ten and 35, and their specific jobs were maker, driller, carver and finisher. Interestingly, of the 21 men in the button trade, 12 were born in Birmingham, Warwickshire which had a much larger button making industry than Sheffield.

Most of the skilled fluters worked with two materials - ivory and pearl (Fig. 4).There was also an 'inlayer' of pearl listed, which might include fine wire decorations or a 'shield' inlay. These shields were common on penknives where they might be made of silver and were intended to take an engraved name or monogram. This was a highly skilled items. They included ivory handled table knives and forks, billiard balls, ivory cigar cases, a pair of ivory ornaments in glass shades, 250 ivory address cards and a gold mounted locket with a portrait painted on ivory. The locket had belonged to Miss Mary Ann Armitage, a school mistress, who also claimed for 7 shillings a week, loss of wages. This was less than a woman boring ivory buttons and, at the rate given above, it would take a whole week's wages to buy a pair of shoes.

process, especially with pearl, which cracks easily.

This method of cutting complex shapes is done with a 'two leg parser', a lowtech, but highly effective way of cutting shapes to a given depth ${ }^{16}$. The author has observed this in operation. The cutler uses a bow drill, placed against a breast

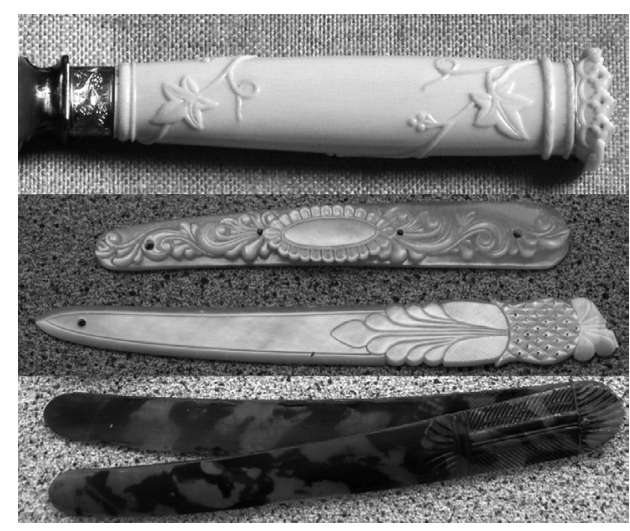

Fig. 4. - Examples of decorated handle and open razor scales; top, ivory knife handle; centre pearl scales; bottom, pressed and stained horn scales. 
plate. The bow rotates the parser drill which has two legs, slightly springy, the ends being cut and sharpened to the required depth of the inlay. A metal cut-out template is held with the pearl scale in a vice and as the parser rotates, the two ends of the legs, pass each other round and round the inside of the template, removing the pearl to the exact shape and depth. A single leg parser drill was also used for boring holes in buttons and for making the rivet holes in knife handle scales. Although it is a simple and effective tool, it was essential that the worker was at the same height as the vice on the bench - difficult for young children, who would stand on a stool and the pressure required made workers' chests ache.

\section{Stag and horn}

The searches in the census and flood claims have revealed confusing terminology. Several people described themselves as working with 'stag horn' - whether it means the keratinous cattle horn treated to imitate stag, or simply the term for the horn from any species of deer. These two materials - stag and horn - will therefore be discussed together.

Although stag was not as expensive as ivory or pearl, it was the choice material for certain types of knives. Horns from a wide variety of deer were imported into Britain from Africa and India, as well as the antlers from indigenous animals. The rough surface was prized for everyday knives, and antler tips were popular as matching handles of carving knives and forks. Like bone, antlers had a spongy core and like bone, the handle lengths could be sawn longitudinally to produce pairs of scales to fit each side of a flat knife tang, or each side of a pocket knife. Cost was an important factor and to reduce the costs, imitation stag was made from bone. Bone could be stained, pressed or filed to produce the ridged surface of antler and was called 'bone stag'.

One of the recurring trade terms in the census is that of 'scale presser'. This is a technique which had been used for centuries as the probate records in Sheffield show cutlers had pressing plates and pressing vices ${ }^{17}$. The processus es lengths of softened bone and squeezing and pressing them between a pair of heated metal plates, which ware engraved to simulate the rough surface of the antler. A similar process involved thin pieces with softened horn, which is thermoplastic, and when pressed in dies will give surface decoration. Thin slices of horn were also used as scales for open razors and knives and the keratinous horn could also be stained to imitate tortoiseshell (Fig. 5).

In the census searches, only one person is described specifically as softening horn - a ten year old boy. The sequence of processes was similar to those in other materials, 21 cutters, 37 pressers and 17 turners, with a further 21 people involved in making buttons and combs. 


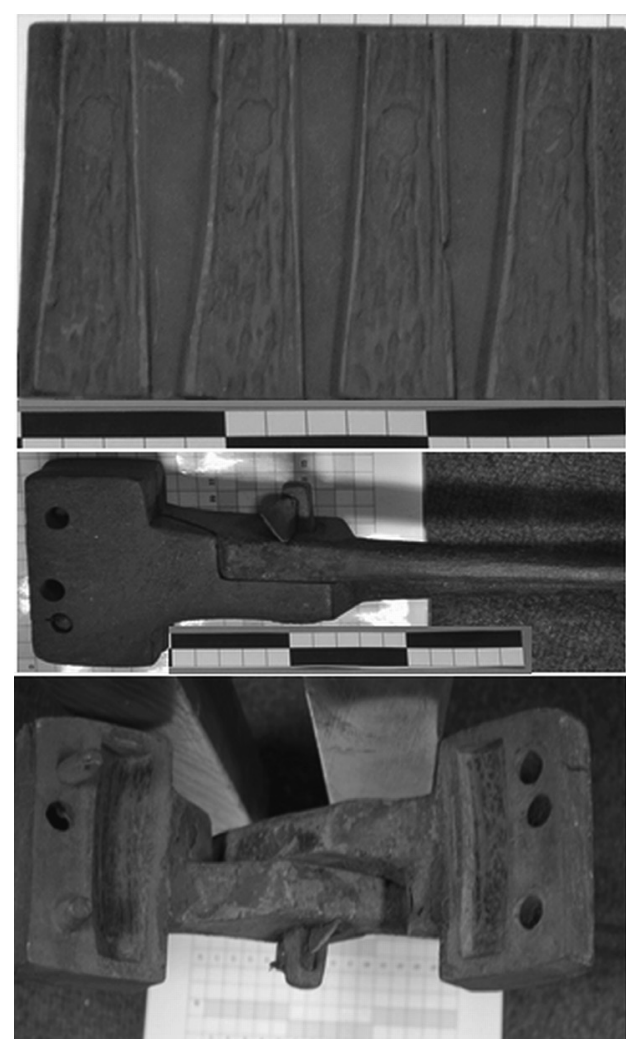

Fig. 5. - Scale pressing; top, engraved plate to press horn giving texture and a shield; centre, pressing vice, closed; bottom, pressing vice open showing engraved dies for bone stag.

\section{Conclusions}

The online accessibility of data has allowed for this and future analysis of the people working in the subsidiary trades of handle making in Sheffield in the 1860s. The census provides data the age range and sex of the work force, indicating few women were involved in handle making. As schooling was not compulsory in the 1860s, very young children were employed in dreadful conditions, often alongside their parents. It was this factor that drove the commissioners to inquire into the conditions of child employment.
These larger merchants claimed for handles and scales in horn and stag, sometimes specifying they were pressed scales. James Thorpe, a horn cutter, claimed for 4500 horn cuts destroyed and a further 700 damaged. His saws were damaged and he had to pay two men 88 shillings for eight days work, washing and cleaning horns. Robert Armitage, a cutler, lost just over a thousand horn scales which he had purchased as handles for his pocket knives. Some were specified as 'pressed' and included buffalo horn. This was horn from water buffalo, which has a bony core and keratinous outer sheath. It is an attractive material used for pocket knives and hunting knife handles. It is not mentioned in the flood claims and census details sufficiently to include here as a separate group.

The 1861 census provides a quantitative basis for further socio-economic conclusions drawn from the compensation claims. It is possible to show, even with this random small sample, that the trade in animal hard parts was enormous in Sheffield. Merchants carried stocks of bones, elephant tusks, dust and horns, measured in tons, details of which come from only one part of Sheffield, that is, along the route of the flood waters. One must assume that the rest of Sheffield was operating at much the same level. 
Finally, the claims for compensation after 1864 flood reveal intimate details of people lives. Because tenement factories were situated alongside the flooded river Don, the loss of workers' earnings gives information on purchasing power.
Valuations of property and personal goods can be taken as reasonably accurate, even if there was the tendency to 'inflate' losses. But the most astonishing aspect of all this data is the amount of dust which was generated!

\section{Notes}

1. G.I.H. Lloyd, The Cutlery Trades, An Historical Essay in the Economics of Small-Scale Production, 1913, reprint Londres, 1968.

2. Sidney Pollard, A History of Labour in Sheffield, Liverpool, 1959.

3. Sonia O'Connor, Caroline Solazzo, and Matthew Collins, "Advances in identifying archaeological traces of horn and other keratinous hard tissues", Studies in Conservation, vol. 60, 2015, p. 393-417, online : [http://www.maneyonline. com/doi/abs/10.1179/2047058414Y.0000000134? $\mathrm{af}=\mathrm{R}]$.

4. William Fisher, "On the supply of Shells, Horns, Bones, and Woods, used in the Cutlery Trades of Sheffield", Proceedings of the Geological and Polytechnic Society of the West Riding of Yorkshire 3, 1849-57, p. 450-456.

5. Charles HoltzApfFel, John Jacob HoltzAPFFEL, Turning and Mechanical Manipulation, publisher Holtzapffel and Co, Londres, 1850, p. 1038-1102.

6. Samuel Harrison, A Complete History of the Great Sheffield Flood, Londres and Sheffield, 1864, republished Evans \& Longley Associates, Dewsbury, 1974.

7. Sheffield Flood Claims, online :[https:// www2.shu.ac.uk/sfca/].

8. 1861 British Census, online : [http://www. freecen.org.uk/].

9. Alkali Act, 1863 Report from the Commissioners, Children's Employment, Cutlery, vol. 8, 1864, p. 41-47.

10. Stephen BAKER, Archaeological Evaluation and Mitigation at Sylvester Street, Sheffield, ARCUS, 2006, online : [http://archaeologydataservice. ac.uk/archsearch/record.jsf?titleId=1901784].

11. Equivalent income - $£ 1$ in $1864=£ 88=$ $€ 105.6$ in 2016. Conversion table - Pre-decimal
British currency : 12 pennies $(d)=1$ shilling; 20 shillings $=£ 1$. Decimal currency: 100 pence $(p)$ $=£ 1$, according to 'Measuring Worth',online : [https://www.measuringworth.com/].

12. Report from the Commissioners, Children's Employment, Cutlery, vol. 8, 1864, p. 45.

13 George Foard McGinnes, M.D., DR.P.H., and Forrest SPINDle, "Erysipeloid Condition Among Workers in a Bone Button Factory Due to the Bacillus of Swine Erysipelas", read to the Epidemiology Section of the American Public Health Association, $62^{\text {nd }}$ annual meeting, Indianapolis, 1933, online : [https:/ / www.ncbi.nlm.nih.gov/pmc/articles / PMC1558484/].

14. Joseph Rodgers and Sons, Under Five Sovereigns, Sheffield, not dated, p. 26, online : [https: / / www.eggintongroup.co.uk/assets / files/PDFs /Under\%20Five\%20Sovereigns.pdf].

15. "Ivory.-Sheffield cutters and cutlery manufacturers", The Times [Londres, England] 29 Jan. 1883, online : [http://www.gale.com/ the-times-digital-archive/].

16. Geoffrey Tweedale, The Forgotten Art of the Two-leg Parser, online : [http://contrib2.wkfinetools.com/TweedaleG/tlParser / tlParser-01.asp].

17. Joan UnwIN, "The versatility of bone, ivory and horn -their uses in the Sheffield cutlery industry", Anthropozoologica, n ${ }^{\circ}$ 1, vol. 49, 2014, p. 121-132, online : [http://sciencepress.mnhn. $\mathrm{fr} / \mathrm{en} /$ periodiques / anthropozoologica / 49/1-0/ la-polyvalence-de-l-os-de-l-ivoire-et-de-la-cornel-industrie-de-coutellerie-de-sheffield]. 